Canadian University Music Review

Revue de musique des universités canadiennes

\title{
Iain Fenlon, ed. Early Music History I: Studies in Medieval and Early Modern Music. Cambridge: Cambridge University Press, 1981, viil, 381 pp.
}

\section{Bryan Gillingham}

\section{Numéro 3, 1982}

URI : https://id.erudit.org/iderudit/1013837ar

DOI : https://doi.org/10.7202/1013837ar

Aller au sommaire du numéro

Éditeur(s)

Canadian University Music Society / Société de musique des universités canadiennes

ISSN

0710-0353 (imprimé)

2291-2436 (numérique)

Découvrir la revue

Citer ce compte rendu

Gillingham, B. (1982). Compte rendu de [Iain Fenlon, ed. Early Music History I: Studies in Medieval and Early Modern Music. Cambridge: Cambridge University Press, 1981, vii, 381 pp.] Canadian University Music Review / Revue de musique des universités canadiennes, (3), 222-225. https://doi.org/10.7202/1013837ar

All Rights Reserved (C Canadian University Music Society / Société de musique des universités canadiennes, 1982
Ce document est protégé par la loi sur le droit d'auteur. L'utilisation des services d’Érudit (y compris la reproduction) est assujettie à sa politique d'utilisation que vous pouvez consulter en ligne.

https://apropos.erudit.org/fr/usagers/politique-dutilisation/ 
IAIN Fenlon, ed. Early Music History I: Studies in Medieval and Early Modern Music. Cambridge: Cambridge University Press, 1981, vii, $381 \mathrm{pp}$.

Because of its attractive hard-cover binding and varied content, Early Music History, at first glance, resembles a Festschrift or specialized collection of essays by different authors on disparate subjects. It clearly equals the best of the Festschriften in the quality of its contributions and production processes. The research behind its submissions is thorough, which might be expected in view of the fine editorial board comprised of eleven eminent scholars from Britain and the United States; the printing is clear and free from typographical errors, the paper is of a durable bond, and the volume is generously illustrated with black and white facsimiles and phot ographs as well as transcriptions and tables of various sorts. In short, it employs the best materials in both physical and conceptual terms. The surprise is that it is the first issue of an annual journal, not an isolated publication.

Since the essays in Early Music History I address mat ters from the tenth to seventeenth century, perhaps the fairest way to assess the content is to measure it against the implicit and explicit goals of the editor(s) instead of ravaging it piecemeal. To do this, we might begin with the title which of necessity must define the limits of the periodical, for this and subsequent installments. One assumes from the main title that Early Music History purports to examine music (and its adjuncts) from at least the seventeenth century (this is confirmed in the preface) and before, although there are some who would also consider contemporaries of J.S. Bach to be exponents of "early music." What, if anything, does the subtitle, "Studies in Medieval and Early Modern Music," convey? It suggests that ancient music is not to be a part of the curriculum, and that medieval and the neologistic "early modern" music are to be. The term "medieval" can be loosely accepted in application to music up to about 1450 , even though hardened medievalists might prefer to cut off the period earlier, say in the thirteenth century. The subtitle informs us that we might expect something from the period 400-1450, less perhaps a mere 200 years, or portion thereof. Early modern music, which we are also to expect, must therefore be the body of music appearing after the Middle Ages up to and including the seventeenth century. A certain editorial discomfort is understandable in allowing renaissance and baroque music to be considered "early," since a vast quantity of medieval music remains. Yet the inclusion of the oxymoronic phrase "early modern," though it informs us of the erudition of the editors in knowing that music from 1450-1700 is not really early, helps little in establishing the chronological parameters of the journal. Furthermore, it is amusing that the bulk of the first volume deals with information from the twelfth to the sixteenth century, a rather late third of the time period suggested. The editors might have allowed the main title to stand alone and, through 
normal selective processes and/or editorial admonition, allowed the content to define the title. As it is, the subtitle is an unfortunate blemish appearing in a very prominent place.

Further information concerning the goals of Early Music History is offered in a one-page preface to Volume I and in an advertising brochure which preceded it. Several perceived needs have prompted the journal's inception: to provide an outlet for publication of early studies, since space elsewhere is insufficient or declining; to encourage the best in international scholarship in the field; to promote interdisciplinary approaches; and to capitalize on "dramatically expanded" musicological methods developed recently. There is no doubt that the inaugural issue succeeds in achieving the first two of these objectives. Anyone who has been forced to wait years in the publication "queues" of the available periodicals would welcome this new forum for intellectual exchange. Its manuscript studies, analytical work, criticisms, and socio-musical enquiries attain a very high level of scholarship. The other two purposes are exaggerated somewhat as novel and call for further comment.

The notion that musical scholarship has been guilty of ignoring "the economic, political and social ramification of research" (p. vii), that the contextual has been neglected, is not well-founded. In this century there have been innumerable "life and works" studies, explorations of patronage and courtly milieus, explanations of church rites and rituals, examinations of pay lists and archival records, and biographies of various musicians from minstrels to aristocrats, some of which have seriously neglected purely musical concerns. What musicology needs, and has always needed, is not so much a "wider range of evidence" (music history is not a serialized crime thriller) as a more thorough and balanced processing of the available information, but not necessarily to the exclusion of more focussed work which still has its place. Even if the editors of Early Music History are guilty of mildly distorting the nature of current research, their open-mindedness in demonstrating a willingness to accept various approaches is laudable, and is realized to an extent in their first effort.

In Volume 1, a number of the articles resort to consultation of material which is not exclusively musical. For example: Bonnie Blackburn ("A Lost Guide to Tinctoris's Teachings Recovered") discusses the rivalry between Gafurius and Tinctoris, and their pedagogical methods, as exemplified in two Italian manuscripts dating from 1478-1520; Lance Brunner ("A Perspective on the Southern Italian Sequence") points out the regional, East Frankish, Norman, and Aquitanian socio-political influences and policies affecting the Italian sequence repertory; David Bryant ("The 'Cori spezzati of St. Marks': Myth and Reality") establishes the liturgical and spatial exigencies, and the nature of required performing forces, including the roles of organists, instrumentalists, singers, and conductors, for Venetian polychoral music; Joyce Irwin ("The Mystical Music of Jean Gerson") delves into the philosophical and theological 
implications of the mystical music treatises of Gerson from the 1420 s and relates them to Reformation thought; Peter Lefferts ("Two English Motets on Simon de Montfort") thoroughly researches the life of Simon de Montfort and relates the details of two late thirteenth-century English motets which refer to him; and Susan Rankin ("The Mary Magalene Scene in the 'Visitatio sepulchri' Ceremonies") touches on cult ritual, didacticism, and popular spectacle with reference to her subject. Often the excursions into these non-musical areas are subordinate to other musical concerns, such as specific pieces, manuscript inventories, dating problems, and theoretical difficulties. Reinhard Strohm ("European Politics and the Distribution of Music in the Early Fifteenth Century") remains in the social and political world to a greater extent in examining the exchange of musical ideas through dynastic alliances, monastic orders, and travelling musicians, adopting the approach that "music" is "the illuminated border in the book of history" (p. 323). The editors have succeeded in encouraging the use of various contextual phenomena, even though this approach is probably not as innovative as they presume.

A grievance expressed in the preface, that "much musicological writing presents by implication a formidable orthodoxy in which history is perceived as a succession of paradigms of musical language, style and form" (p. vii) applies not only to the imagined neglect of interdisciplinary challenge but is also extended to include the methodology of musical research. The editorial policy of Early Music History expressly favors "new techniques" or "new methodological ideas," without actually explaining what these are. One is led to ask, what, indeed, are the "techniques" employed in Early Music History I? And are they strikingly new? In its diversified articles one may find the following methods in varying degrees: description (of manuscripts, music, churches, people, documents), comparison, inventory, archival investigation, analysis (of music and notation), exemplification, paleography (textual and musical), translation, speculation, documentary support, and photographic reproduction. The four book reviews at the end of the volume are well written, but quite standard critical essays. Margaret Bent and Roger Bowers ("The Saxilby Fragment") employ ultra-violet light to discover mistakes, erasures, and corrections. Christopher Reynolds ("The Origins of San Pietro B80") associates archival references with a surviving fifteenth-century manuscript, a feat usually impossible to accomplish. The answer to the second question above, with the possible exception of the last method cited, is that none of the techniques above is new, nor are others in evidence. All of them, even the relatively recent use of ultraviolet light, have been standard processes in humanistic endeavors for a very long time. New methods do not account for the excellence of Tom Ward's, "A Central European Repertory in Munich, Bayerische Staatsbibliothek, Clm 14274;" the repertory is interesting, the writing and research skilled and thorough - these are merits enough.

It is curiously quixotic and paradoxical that the editor(s) should 
feel obliged to rationalize a journal devoted to the past as a reflection of the "new" and "modern." The past is not necessarily dull, musty, and boring, nor has it always been handled ineptly, as we all know. So why the protest? In spite of the curiosites inherent in the subtitle and editorial policy of Early Music History, there can be no question that it is a welcome and valuable addition to the periodical literature. It promises to be a solid, catholic, and vigorous journal of the highest order. Although its stated intention is "to stimulate further exploration of familiar phenomena through unfamiliar means," most students of early music will be very pleased if it continues to explore unfamiliar phenomena through familiar means as it does in the first volume.

Bryan Gillingham

We are grateful to the editor of Fanfare magazine for permission to reprint the following reviews of McGill University Records and pleased to direct the attention of our members and readers to this important recording project. The recordings are available at a cost of $\$ 9.95$ per disc from McGill University Records, 555 Sherbrooke Street West, Montréal, P.Q., Canada, H3A 1E3.

WYSCHNEGRADSKY: Two Concert Etudes, Op. 19: Two Fugues, Op. 33; Integrations, Op. 49. MATHER: Sonata for Two Pianos. HAMBRAEUS: Carillon for Two Pianos. Pierrette LaPage and Bruce Mather, duo-pianists. McGILL UNIVERSITY RECORDS 77002.

Wyschnegradsky. Not one concertgoer in 10,000 is likely to have ever heard his name, much less ever heard his music. Ivan Wyschnegradsky is one of those unique composers of advanced musical esoterics that emerged in the musically fertile World War I and pre-Depression era. Of these early atonalists and microtonalists, several examples of the music of Alois Hába, Carrillo, and, lately, Ornstein, can be found on disc, though only the Ornstein discs are easy to come by; the Swedish label Caprice has given the first discographical light to Roslavetz ( see Fanfare II:4, p. 99). But for Mossolov (disregarding the famous three-minute excerpt from his gimmicky Iron Foundry), Lourié, Ponc, Pâque and others, total obscurity of their innovative works remains. And until the present Canadian release, Wyschnegradsky belonged to the later group.

Born in Russia in 1893 and resident in Paris since 1920, the stillactive Wyschnegradsky [Wyschnegradsky died in September 1979, ed.] has maintained an isolated 60-year embrace of microtonality. His music has had only occasional concerts; and for all the attention he has gotten, 